\title{
鉛直振動を受ける円筒容器内の二層液体界面に発生する 内部波とその発生限界 \\ SLOSHING OF TWO IMMISCIBLE LIQUIDS CONTAINED IN CIRCULAR TANKS SUFFERING FROM VERTICAL VIBRATION
}

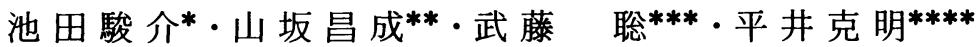 \\ By Syunsuke IKEDA, Masashige YAMASAKA, Satoshi MUTOH and Katsuaki HIRAI
}

\begin{abstract}
Instability of interface between two immiscible fluids was studied theoretically and experimentally. The instability was found to be governed by the Mathieu equation with a damping term, and the third order solution for $\varepsilon$ was obtained, in which $\varepsilon$ is the ratio of periodically varying vertical acceleration to gravitational acceleration. The theory indicates that $1 / 2$-subharmonic motion of the interface is the only possible response to the external vibration, since the unstable regions of the higher harmonic response becomes quite limited if the effect of viscous damping is considered. Several modes of interfacial two-dimensional waves were found in the laboratory tests, of which unstable regions were predicted well by the present theory.

Keywords : circular tank, internal wave, vertical vibration
\end{abstract}

\section{1. 序論}

鉛直振動を受ける場で発生する重力波は復元力が時間 の関数となるためにパラメーター振動となることが知ら れている. 一番簡単な例は Fig.1 のように上下に振動す るU字管内の液面振動にみられ, Mathieu 方程式によっ て液面振動の安定・不安定を論ずることができる.

容器内の液体が鉛直振動外力を受けた場合については 自由表面が外力振動の 1/2-subharmonic 応答すること をF araday が 1831 年に発見して以来, 液面動摇につい てさまざまな研究がなされている，たとえば，Benjamin・Ursell ${ }^{1)}$ は境界条件を線型化し速度ポテンシャル を用いて解析を行い, 液面が不安定となる領域およびそ のモードを明らかにしている．波高の応答曲線を求める には境界条件の非線型性を考虑した解析が必要となる が, Dodge ら ${ }^{2)}$, 池田ら ${ }^{3)}$ は三次のオーダーまでの非線 型解析を行い, 波形や動水圧の分布についても調べてい る. 以上のような研究は流体力学的興味のほかに, 地震

* 正会員 工博 埼玉大学助教授 工学部建設基礎工学科 ( \%338 浦和市下大久保 255)

** 正会員 工博 埼玉大学助手 工学部建設基礎工学科 (同上)

*** 建設省関東地方建設局

*****越谷市役所

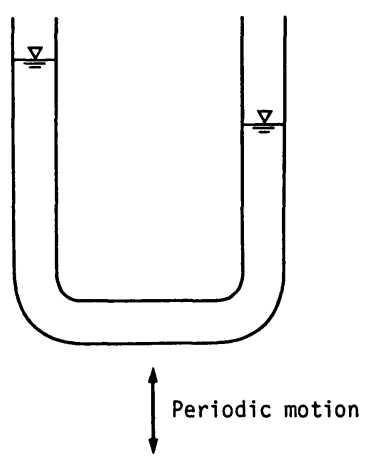

Fig. 1 An example of parametric oscillation.

時の石油タンクの液面動摇や液体燃料ロケットのタンク 内の液面動摇などを明らかにする目的で行われたもので あり，したがって表面波についての取り扱いとなってい る.

一方, 貯液方式が複雑化（たとえば海底貯液タンク） したり, 新しい構造物（たとえばFBR）が構築される につれて用いられる液体も均質なものではなく, 成層液 体や二層液体としての取り扱いが必要とされることが多 くなってきている.上に述べたタンク型FBR（高速増 殖炬）では，地震のような原因で停止した場合，炬心か ら排出される液体ナトリウムが急激に冷却され, それが 
原子炉容器中の高温液体ナトリウム中に流出すると顕著 な成層化現象が発生する。このような場合，界面の動摇 により炉容器には大きな熱衝撃が加わることが予想され ている4).このような内部波については水平振動を受け る場合について Thorpe ${ }^{5)}$, 石川・椎貝 ${ }^{6)}$, 沢本・加藤 ${ }^{7}$ が線形あるいは非線形解析を行っているが，鉛直振動を 受ける場合については取り扱いがなされていない. 大気 と接する表面波に比べて内部波は粘性の影響を受けやす く, 特に前述のような高粘度の液体については粘性の効 果を十分に把握しておく必要がある. パラメータ一振動 では安定・不安定境界を表わす中立曲線の位置が抵抗 （液体の場合には粘性による）によって変化するので, 本論文ではこれらの解析を行うとともに実験により理論 の妥当性を確かめる.

\section{2. 基礎方程式の誘道}

Fig. 2 に示すような半径 $R$ の円筒タンク内に密度 $\rho_{a}$ および $\rho_{b}$ をつ二層液体が密閉されているとする.た だし, $\rho_{a}<\rho_{b}$ であり, 以後添字 $a, b$ はそれぞれ上層, 下層液体に関する量を表わすこととする．このような系 に鉛直交番変位 $A \cos N \omega t$ を加える，ただし，A は振 幅, $N \omega$ は角周波数, $\omega$ は液面動摇の角周波数, $N$ は正 の数である．このとき流体系を支配する運動方程式は液 体の非圧縮, 非回転を仮定すれば, 次の Laplace の式 となる.

$$
\frac{\partial^{2} \Phi}{\partial r^{2}}+\frac{1}{r} \frac{\partial \Phi}{\partial r}+\frac{1}{r^{2}} \frac{\partial^{2} \Phi}{\partial \theta^{2}}+\frac{\partial^{2} \Phi}{\partial z^{2}}=0
$$

ここに， $\Phi$ は速度ポテンシャルである. 境界条件は壁 および上下底で

$$
\frac{\partial \Phi}{\partial n}=0
$$

である.ここに， $n$ は境界に対し外向き法線方向の位置 を表わす．内部境界面では上下層の液体の圧力が等しい こと（力学的条件）と, 内部境界面の移動速度と鉛直流 速成分が等しいこと（運動学的条件）が要求される.す なわち,

$$
\begin{aligned}
& P_{a}=P_{b} \ldots \ldots \ldots \ldots \\
& -\frac{D \eta}{D t}=\frac{\partial \Phi_{a}}{\partial z}=\frac{\partial \Phi_{b}}{\partial z}
\end{aligned}
$$

である.ここに $P$ は圧力, $\eta$ は内部境界面の変位である. 各独立変数ごとに変数分離

$$
\Phi=R(r) Z(z) \Theta(\theta) T(t) \text {. }
$$

を行い, 式（1）を式（2）の境界条件のみを考虑して 解くと, 上下層液体の速度ポテンシャルが次のように求 まる。

$$
\begin{aligned}
\Phi_{a}= & \sum_{m=0}^{\infty} \sum_{n=1}^{\infty} J_{m}\left(\lambda_{m n} r\right) \frac{\cosh \left[\lambda_{m n}\left(z-H_{a}\right)\right]}{\cosh \left(\lambda_{m n} H_{a}\right)} \\
& \times\left(C_{1} \sin m \theta+C_{2} \cos m \theta\right) \cdot T_{a}(t)
\end{aligned}
$$

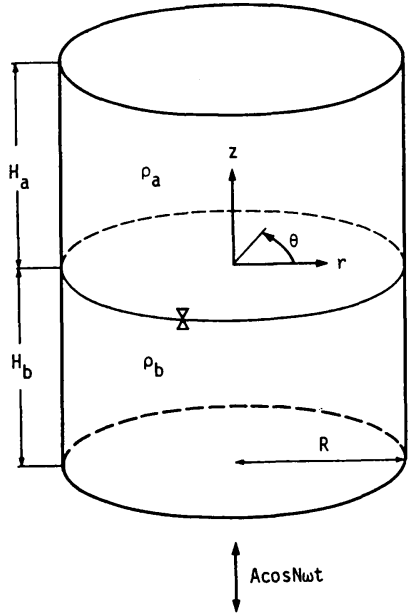

Fig. 2 Definition sketch.

$$
\begin{aligned}
\Phi_{b}= & \sum_{m=0}^{\infty} \sum_{n=1}^{\infty} J_{m}\left(\lambda_{m n} r\right) \frac{\cosh \left[\lambda_{m n}\left(z+H_{b}\right)\right]}{\cosh \left(\lambda_{m n} H_{b}\right)} \\
& \times\left(B_{1} \sin m \theta+B_{2} \cos m \theta\right) \cdot T_{b}(t) .
\end{aligned}
$$

ここに, $C_{1}, C_{2}, B_{1}, B_{2}$ は係数, $J_{m}$ は第一種 $m$ 階 Bessel 関数であり, $\lambda_{m n}$ は方程式

$$
\left.\frac{d J_{m}\left(\lambda_{m n} r\right)}{d r}\right|_{r=R}=0
$$

の根であり，これを満たす零点は円周方向の波数 $m$ に 対して無限に存在し，その固有値の順序を $n(1,2,3$, ‥) としている. 式 (6)，（7）では時間に関する関数 $T_{a}, T_{b}$ が決定していない. 境界面では同一の波動運動 を行うので, $T_{a}, T_{b}$ は等しく, 以後 $T$ として取り扱う. 液体中の圧力は一般化された Bernoulli の定理

$$
\frac{P}{\rho}=\frac{\partial \Phi}{\partial t}-\left(g-A N^{2} \omega^{2} \cos N \omega t\right) z-\frac{v^{2}}{2} \text {. }
$$

から求まる.ここに $g$ は重力の加速度, $v^{2}$ は流体の速 度ベクトルの二乗であるが， $v^{2}$ は境界面の振幅が十分 小さい場合には無視し得る，本論文では内部境界面の動 摇の安定・不安定境界を求めるので, この条件は厳密に 満足される. したがって, 式（3）の境界条件は以下の ようになる.

$$
\begin{aligned}
\rho_{a} & {\left[\frac{\partial \Phi_{a}}{\partial t}-\left(g-A N^{2} \omega^{2} \cos N \omega t\right) \eta\right] } \\
& =\rho_{b}\left[\frac{\partial \Phi_{b}}{\partial t}-\left(g-A N^{2} \omega^{2} \cos N \omega t\right) \eta\right]
\end{aligned}
$$

同様に, 運動学的条件において $\eta$ が十分小さいとすれ ば, 式（4）は以下のようになる.

$$
-\frac{\partial \eta}{\partial t}=\frac{\partial \Phi_{a}}{\partial z}=\frac{\partial \Phi_{b}}{\partial z}
$$

式（10）の両辺を $t$ で偏微分し, 式 (11) を代入して 再び $\eta=0$ とおけば, 


$$
\begin{aligned}
& \rho_{a} \frac{\partial^{2} \Phi_{a}}{\partial t^{2}}-\rho_{b} \frac{\partial^{2} \Phi_{b}}{\partial t^{2}}+\left(\rho_{a}-\rho_{b}\right)\left(g-A N^{2} \omega^{2} \cos N \omega t\right) \\
& \cdot \frac{\partial \Phi_{a}}{\partial z}=0
\end{aligned}
$$

となる. 式（11）に式（6），(7) を代入し， $z=\eta \simeq 0$ とすれば

$$
B_{1} \sin m \theta+B_{2} \cos m \theta=-\frac{\tanh \left(\lambda_{m n} H_{a}\right)}{\tanh \left(\lambda_{m n} H_{b}\right)}
$$

$\cdot\left(C_{1} \sin m \theta+C_{2} \cos m \theta\right)$

が成り立つ. 式 (12) に式 (6), ( 7 ) を代入し, 式 (13) を用いて整理すれば, $T$ に関する微分方程式を得る。

$$
\begin{aligned}
& \frac{d^{2} T}{d t^{2}}+(1-G)\left(g-A N^{2} \omega^{2} \cos N \omega t\right) \\
& \quad \times \frac{\lambda_{m n} \tanh \left(\lambda_{m n} H_{a}\right) \tanh \left(\lambda_{m n} H_{b}\right)}{\tanh \left(\lambda_{m n} H_{a}\right)+G \tanh \left(\lambda_{m n} H_{b}\right)} T=0
\end{aligned}
$$

ここに, $G=\rho_{a} / \rho_{b}$ である:

式（14）は Mathieu 方程式であって, 鉛直振動を受 ける二層液体の境界面に発生する内部波はパラメーター 振動を起こすことが知られる. 一般に外力の角周波数が $N \omega$ で与えられる場合, $0<N<1$ のとき内部波は外力に 対して superharmonic, $N=1$ のとき harmonic, $N>1$ のとき subharmonic 応答をすることとなる. $A=0$ とす ると式（14）は自由振動の方程式となり, この場合の固 有角周波数 $\Omega$ は次のようになる.

$$
\Omega=\left[\frac{(1-G) g \lambda_{m n} \tanh \left(\lambda_{m n} H_{a}\right) \tanh \left(\lambda_{m n} H_{b}\right)}{\tanh \left(\lambda_{m n} H_{a}\right)+G \tanh \left(\lambda_{m n} H_{b}\right)}\right]^{\frac{1}{2}}
$$

式（15）を用いて式（14）を書き直せば,

$$
\frac{d^{2} T}{d t^{2}}+\Omega^{2}\left(1-\frac{A N^{2} \omega^{2}}{g} \cos N \omega t\right) T=0
$$

次に減衰効果について考える. 実在液体には粘性があ るために減衰を考慮する必要がある.このような波動運 動によって生ずる振動流れでは, 渦度を有する領域は夕 ンク境界面および内部液体境界面のごく近傍に限られる （渦度の source は固体境界壁および密度界面であり， 渦度の存在する厚さは $\delta=\sqrt{2 \nu / \omega}$ の程度であることに よる,ここにンは動粘性係数) ので, 液体の大部分の 領域では無渦運動として取り扱ってよい. また, 前にも 述べたように現在取り扱いの対象としているのは内部境 界面の安定・不安定の中立曲線を決めることであるの で，微小振幅波として取り扱うことができる. 以上から Stokes 層厚さ $\delta$ を基準とした Reynolds 数は非常に小 さく, したがって抵抗項は $d T / d t$ に比例するとおくこ とができる. 以上から粘性を考慮した場合の支配方程式 は，式（16）に減衰項を付加し，

$$
\frac{d^{2} T}{d t^{2}}+2 h \Omega \frac{d T}{d t}+\Omega^{2}\left(1-\frac{A N^{2} \omega^{2}}{g} \cos N \omega t\right) T=0
$$

となる.ここに, $h$ は無次元の減衰率である. 方程式を 完全に無次元化するために, $\tau=N \omega t$ と置き, 式 (17) を変形すれば,

$$
\frac{d^{2} T}{d \tau^{2}}+2 \mu \frac{d T}{d \tau}+\left(q^{2}-\varepsilon \cos \tau\right) T=0
$$

となる.ここに

$$
\mu=\frac{h \Omega}{N \omega}, \quad q^{2}=\frac{\Omega^{2}}{N^{2} \omega^{2}}, \quad \varepsilon=\frac{A \Omega^{2}}{g}
$$

である. 式（18）が, 液体の粘性を考虑した場合の界面 の安定・不安定を決定する基礎方程式である.

\section{Mathieu 方程式の高次解}

式（18）は構造工学の分野においてもよく現われる. たとえば, Bolotin ${ }^{8)}$ は弾性構造物の動的安定・不安定 問題に関連するパラメーター振動について詳述してい る. Bolotin の解法は $T(t)$ を Fourier 級数で展開し, 各調和および分数調和波ごとに $\varepsilon \ll 1$ の場合の解を求め るものである. また，構造工学の分野では多自由度振動 を伴うことが多いので数值解法が行われている ${ }^{9) \sim 11)}$.

一方, 本論文で取り扱われているような振動系では, $\varepsilon$ (重力の加速度に対する鉛直加速度の比に比例する量) が十分小さいとは限らないので, $\varepsilon$ に関する高次解を求 める必要がある. Mathieu 方程式, 式 (18)，に含まれ

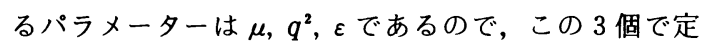
まる面上のどこで安定な解, 不安定な解が存在するかを 調べればよい.すすなわ，安定な解と不安定な解が存在 する領域の境界では $T$ が周期解をもつことを仮定して, 3 個のパラメーターの間の関係を調べればよい. 式 (18) において, $\varepsilon \rightarrow 0$ のとき, もし $\mu$ が正の有限な值であれ ば,方程式は完全な周期解をもつことはなく減衰する解, すなわち安定な解をもつことになる. したがって, 完全 な周期解をもつためには $\varepsilon \rightarrow 0$ のとき， $\mu \rightarrow 0$ でなけれ ばならない.したがって， $\mu$ は次のように展開される.

$$
\mu=\varepsilon \beta_{1}+\varepsilon^{2} \beta_{2}+\varepsilon^{3} \beta_{3}+\cdots
$$

このとき (すなわち, $\varepsilon \rightarrow 0$ のとき), 式 (18)は $d^{2} T /$ $d t^{2}+q^{2} T=0$ となり, 周期解 $e^{i q t}$ をもつ. $\varepsilon \rightarrow 0$ におい て,この調和解に一致しなければならないので, $q^{2} を$ 以下のように $\varepsilon$ のベキで展開する.

$$
q^{2}=\frac{1}{N^{2}}+\varepsilon \alpha_{1}+\varepsilon^{2} \alpha_{2}+\varepsilon^{3} \alpha_{3}+\cdots
$$

式（19）を参照して, 式 (21) は $\varepsilon \rightarrow 0$ の極限で $\omega=\Omega$, すなわち内部波の角周波数は固有角周波数に等しく外力 の角周波数の $1 / N$ になることを表わしている．以上の 展開に対応して $T(\tau)$ を次のように置く.

$$
T(\tau)=T_{0}+\varepsilon T_{1}+\varepsilon^{2} T_{2}+\varepsilon^{3} T_{3}+\cdots
$$

式 $(20),(21),(22)$ を式 (18) に代入し, $\varepsilon$ の各才ー ダーごとにまとめると 
$\varepsilon^{0}$ のオーダー：

$$
\frac{d^{2} T_{0}}{d \tau^{2}}+\frac{1}{N^{2}} T_{0}=0
$$

$\varepsilon^{1}$ のオーダー :

$$
\frac{d^{2} T_{1}}{d \tau^{2}}+2 \beta_{1} \frac{d T_{0}}{d \tau}+\left(\alpha_{1}-\cos \tau\right) T_{0}+\frac{1}{N^{2}} T_{1}=0 \cdots
$$

$$
\varepsilon^{2} \text { のオーダー : }
$$

$$
\begin{gathered}
\frac{d^{2} T_{2}}{d \tau^{2}}+2 \beta_{2} \frac{d T_{0}}{d \tau}+2 \beta_{1} \frac{d T_{1}}{d \tau}+\alpha_{2} T_{0} \\
+\left(\alpha_{1}-\cos \tau\right) T_{1}+\frac{1}{N^{2}} T_{2}=0 \cdots
\end{gathered}
$$

$\varepsilon^{3}$ のオーダー :

$$
\begin{aligned}
& \frac{d^{2} T_{3}}{d \tau^{2}}+2 \beta_{3} \frac{d T_{0}}{d \tau}+2 \beta_{2} \frac{d T_{1}}{d \tau}+2 \beta_{1} \frac{d T_{2}}{d \tau}+\alpha_{3} T_{0} \\
& +\alpha_{2} T_{1}+\left(\alpha_{1}-\cos \tau\right) T_{2}+\frac{1}{N^{2}} T_{3}=0
\end{aligned}
$$

となる。

前述のように, 内部波は外力に対しては $1 / 2$-subharmonic 応答 $(N=2)$ することが予想されるので, まず $N=2$ の場合について解を求める. 式 (23) より $T_{0}$ は

$$
T_{0}=a \cos \left(\frac{1}{2} \tau+\phi\right) \text {. }
$$

ここに, $a$ は $T_{0}$ に関する振幅で波高に比例する量, $\phi$ は位相差である. 式 (27) を式 (24) に代入し, 整理す れば次式を得る。

$$
\begin{aligned}
& \frac{d^{2} T_{1}}{d \tau^{2}}+\frac{1}{4} T_{1}=a\left[\left(\beta_{1} \cos \phi+\alpha_{1} \sin \phi\right.\right. \\
& \left.+\frac{1}{2} \sin \phi\right) \sin \frac{1}{2} \tau+\left(\beta_{1} \sin \phi-\alpha_{1} \cos \phi\right. \\
& \left.+\frac{1}{2} \cos \phi\right) \cos \frac{1}{2} \tau-\frac{1}{2} \sin \phi \sin \frac{3}{2} \tau \\
& \left.+\frac{1}{2} \cos \phi \cos \frac{3}{2} \tau\right]
\end{aligned}
$$

$T_{1}$ が周期解をもつには, $\sin \tau / 2, \cos \tau / 2$ の係数（永 年項）が 0 でなければならない.すなわち,

$$
\left(\alpha_{1}+\frac{1}{2}\right) \sin \phi+\beta_{1} \cos \phi=0 \text {. }
$$

$\beta_{1} \sin \phi-\left(\alpha_{1}-\frac{1}{2}\right) \cos \phi=0$

式 (29), (30) から $\alpha_{1}, \beta_{1}$ の関係として

$$
\alpha_{1}= \pm\left(\frac{1}{4}-\beta_{1}^{2}\right)^{\frac{1}{2}}
$$

を得る. まず，以上の $\varepsilon^{1}$ のオーダーまでの項から安定・ 不安定境界を求める. 式 (20), (21) から

$$
\begin{aligned}
& \mu=\varepsilon \beta_{1} \cdots \ldots \\
& q^{2}=\frac{1}{4}+\varepsilon \alpha_{1}
\end{aligned}
$$

である.また, 式 (19) から

$$
\mu=q h \cdots
$$

となる，よって，式（32），(34）から

$$
\beta_{1}=\frac{q h}{\varepsilon}
$$

また， $\alpha_{1}$ は式（31）から

$$
\alpha_{1}= \pm\left(\frac{1}{4}-\frac{q^{2} h^{2}}{\varepsilon^{2}}\right)^{\frac{1}{2}}
$$

となる. 式 (33)，(36) から，q2ついて解き

$$
q^{2}=\left(\frac{1}{4}-\frac{h^{2}}{2}\right) \pm\left[\left(\frac{1}{4}-\frac{1}{2} h^{2}\right)^{2}-\left(\frac{1}{16}-\frac{1}{4} \varepsilon^{2}\right)\right]^{\frac{1}{2}}
$$

を得る. 式 (37) が $\varepsilon^{1}$ のオーダーを考虑した場合（第 1 近似解）の 1/2-subharmonic 応答の安定 - 不安定領 域の境界を示し, $T(t)$ を Fourier 展開して求めた Bolotin の解と一致する.

$\varepsilon^{2}$ のオーダーの解 (第 2 近似解) を求めるには次の ように行う. 式 (28) から永年項は0であることに注意 して, $T_{1}$ の解は

$$
T_{1}=a\left(\frac{1}{4} \sin \phi \sin \frac{3}{2} \tau-\frac{1}{4} \cos \phi\right)
$$

である. 式 (27)，(38) を式 (25) に代入し， $T_{2}$ を求め, 再び $\sin \tau / 2, \cos \tau / 2$ の係数を 0 とおくと, $\alpha_{2}, \beta_{2}$ が 求まり,

$$
\alpha_{2}=-\frac{1}{8}, \quad \beta_{2}=0
$$

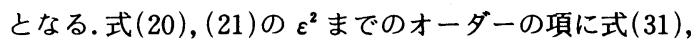

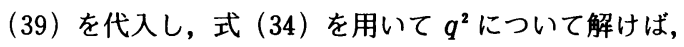

$$
\begin{aligned}
& q^{2}=\left(\frac{1}{4}-\frac{1}{2} h^{2}-\frac{1}{8} \varepsilon^{2}\right) \pm\left[\left(\frac{1}{4}-\frac{1}{2} h^{2}-\frac{1}{8} \varepsilon^{2}\right)^{2}\right. \\
& \left.-\left(\frac{1}{16}-\frac{5}{16} \varepsilon^{2}+\frac{1}{64} \varepsilon^{4}\right)\right]^{\frac{1}{2}}
\end{aligned}
$$

となる. $\varepsilon^{3}$ のオーダーの解（第 3 近似解）は同様の操 作を行えば

$$
\alpha_{3}=-\frac{1}{16} \alpha_{1}, \quad \beta_{3}=-\frac{3}{16} \beta_{1}
$$

となる. 第 3 近似解では $\beta_{1}$ は式 (35) ではなく, 式 (20), (34), (39), (41) より

$$
\beta_{1}=q h /\left(\varepsilon-\frac{3}{16} \varepsilon^{3}\right) \text {....... }
$$

となる.これを式 (31)，（41）に代入して得られる $\alpha_{1}$, $\alpha_{3}$ および式 (39) を式 (21) に代入して, 安定・不安 定境界を表わす式として

$$
\left(q^{2}-\frac{1}{4}+\frac{1}{8} \varepsilon^{2}\right)^{2}=\left(\varepsilon-\frac{\varepsilon^{3}}{16}\right)^{2}\left[\frac{1}{4}-\left(\frac{q h}{\varepsilon-\frac{3}{16} \varepsilon^{3}}\right)^{2}\right]
$$

を得る. 安定・不安定境界上では, $T=T_{0}+\varepsilon T_{1}+\varepsilon^{2} T_{2}$ $+\varepsilon^{3} T_{3}+\cdots$ の振動を行う.

以上求められた解を用いて, Fig. 3 に減衰がない場合 $(h=0)$ について, 1/2-subharmonic 応答の各オーダー ごとの安定・不安定境界を示す. 第 1 近似解は $\varepsilon$ が大 
きくなると高次解とのずれが大きいが，第 2 近似解は第 3 近似解とほとんど一致しており，第 2 近似解までとれ

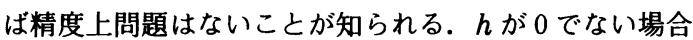
についても第 2 近似解と第 3 近似解はほとんど一致し た.

Fig. 4 は第 3 近似解について無次元減衰率 $h$ を変化さ せ，安定・不安定領域を描いたものである． $h$ が増大す るにつれて,不安定領域が縮小することが示されている.

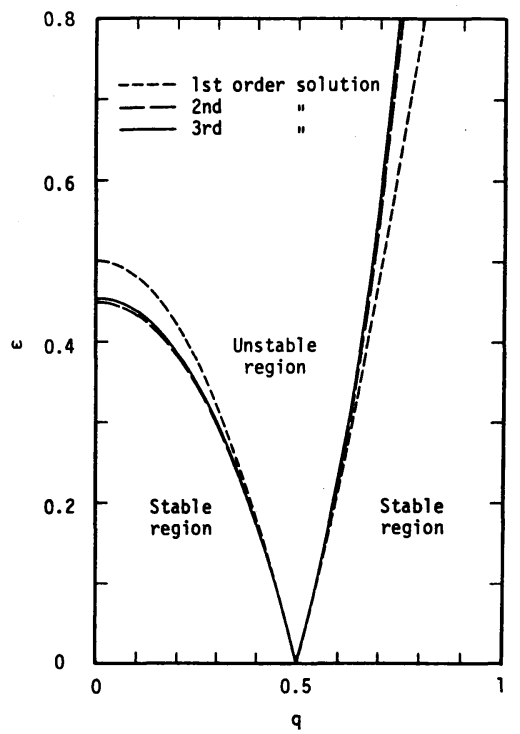

Fig. 3 Comparison of each order of approximation for $1 / 2$ subharmonic response at $h=0$.

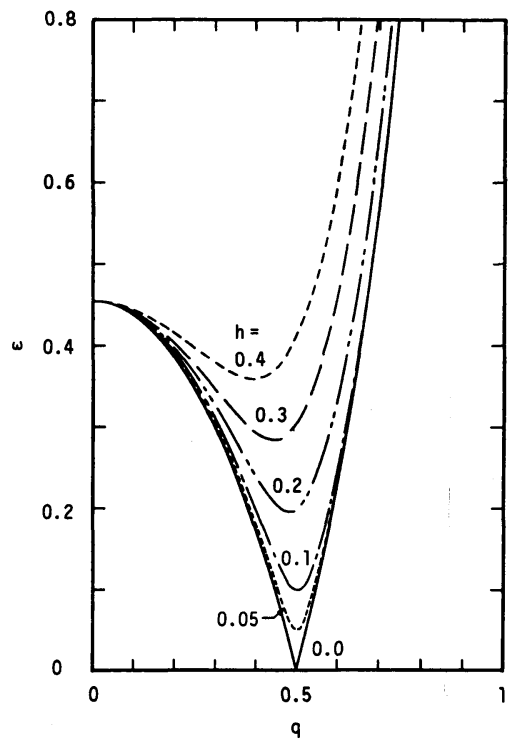

Fig. 4 Stable-unstable boundaries of $1 / 2$ subharmonic response for various values of $h$
たとえば, $h=0.1$ であれば $\varepsilon=0.1$ 程度まで鈶直振動に よる内部波の発生はない.

次に harmonic 応答 $(N=1)$ の場合について述べる. 解法は $N=2$ の場合と全く同様であり,結果のみを示す.

$$
\begin{aligned}
& \alpha_{1}=\beta_{1}=0 \\
& \alpha_{2}=\frac{1}{6} \pm\left(\frac{9}{144}-4 \beta_{2}^{2}\right)^{\frac{1}{2}}, \quad \beta_{2}=\frac{q h}{\varepsilon^{2}}
\end{aligned}
$$

この $\varepsilon^{2}$ のオーダーまでの結果を用いて, 安定・不安定 境界は

$$
q^{2}=\left(1-2 h^{2}+\frac{1}{6} \varepsilon^{2}\right) \pm\left[\frac{9}{144} \varepsilon^{4}+\left(4 h^{2}-4-\frac{2}{3} \varepsilon^{2}\right) h^{2}\right]^{\frac{1}{2}}
$$

となる.

同様に 3/2-superharmonic $(N=2 / 3)$ の場合は

$$
\begin{aligned}
& \alpha_{1}=\beta_{1}=0 \cdots \ldots \ldots \ldots \ldots \ldots \ldots \ldots \ldots \ldots \ldots \ldots \ldots \ldots \\
& \alpha_{2}=\frac{1}{16}, \quad \beta_{2}=0 \cdots \cdots \ldots \ldots \ldots \\
& \alpha_{3}= \pm \frac{1}{32^{2}}-9 \beta_{3}^{2}, \quad \beta_{3}=\frac{q h}{\varepsilon^{3}}
\end{aligned}
$$

となる.この場合には $\varepsilon^{3}$ のオーダーにおいて始めて減 衰の効果が現われる， $\varepsilon^{3}$ のオーダーまでの結果を用い た安定・不安定境界は以下のようである。

$$
\begin{aligned}
& q^{2}=\left(\frac{9}{4}-\frac{9}{2} h^{2}+\frac{1}{16} \varepsilon^{2}\right) \pm\left[\frac{81}{4} h^{2}\left(h^{2}-1\right)\right. \\
& \left.-\frac{9}{16} \varepsilon^{2} h^{2}+\frac{1}{32^{2}} \varepsilon^{6}\right]^{\frac{1}{2}}
\end{aligned}
$$

以上のように $N$ の值を変えて計算を進めていけばよい.

結果はFig. 5 に示されているが，3/2-superharmonic においてすでに不安定領域は非常に狭く，これ以上小さ い $N$ の值について求める必要はほとんどない。また, 同図中で $h=0.05$ ととり, 減衰の効果が不安定領域を

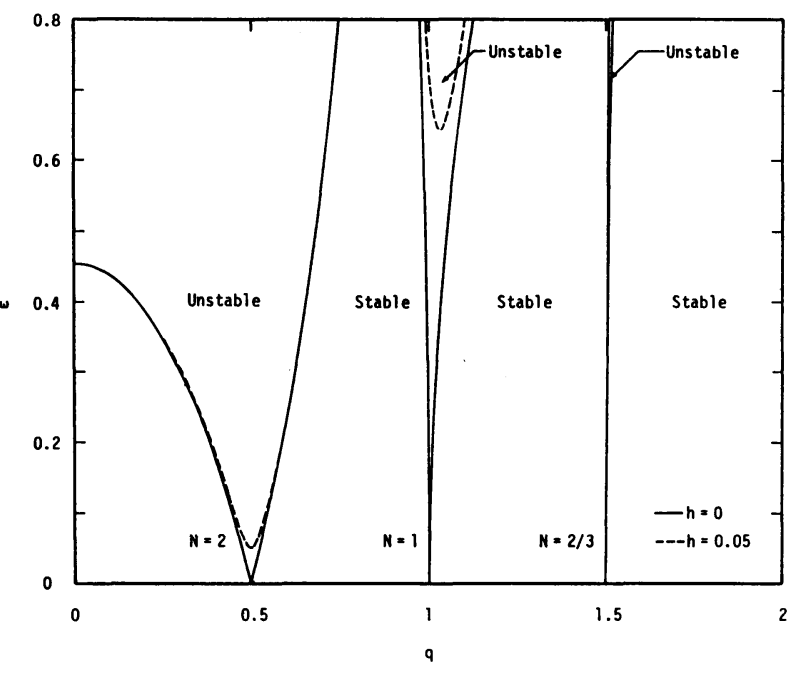

Fig. 5 Stable-unstable regions of Mathieu equation. 
どの程度縮小させるかについて検討している. $N$ の值 が小さくなるにつれて不安定領域が急激に小さくなり， $N=1$ の harmonic 応答では $\varepsilon=0.65$ 程度の鉛直加速度 を与えなければ不安定とならず， $N=2 / 3$ の 3/2-superharmonic では図中にはもはや不安定領域は現 われない.以上から粘性による減衰を考慮した場合には， 実際上 1/2-subharmonic しかあり得ないことが知られ る.

\section{4. 実験}

実験に用いた振動台は埼玉大学工学部建設系所属の島 津サーボパルサーEHV 05105 であり, 鉛直振動を加え る場合の最大投載量は $50 \mathrm{~kg}$ である. 鉛直振動の制御は

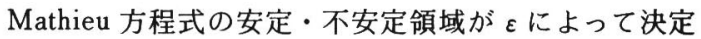
されることから鉛直加速度を変化させる必要があるが, ここでは一定の振幅 $A$ に対し外力の角周波数 $N \omega$ を変 化させて実験を行い, さらに $A$ を変えて再び $N \omega$ を変 化させる方法を用いた。用いた円筒タンクは透明アクリ ル樹脂製で, 内径 $18 \mathrm{~cm}$, 高さ $50 \mathrm{~cm}$, 壁厚 $1 \mathrm{~cm}$ であり, 振動台に固定されている.下層の液体は水, 上層の液体 はテレピン油である，上，下層の深さはそれぞれ $H_{a}=$

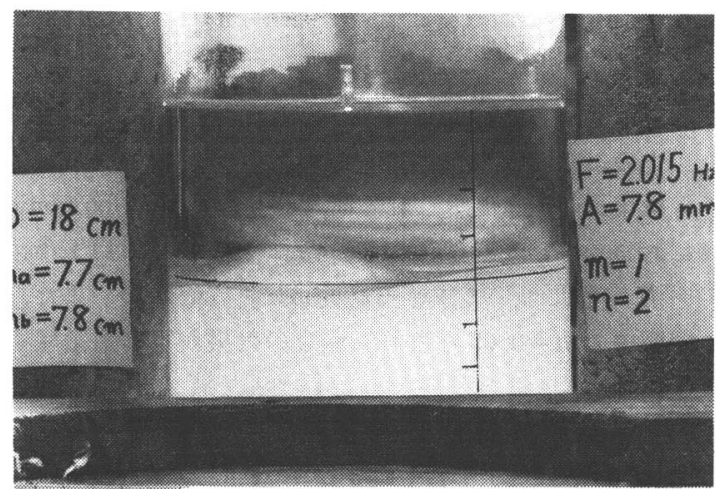

(a) $N \omega / 2 \pi=2.015 \mathrm{~Hz}, \quad m=1, \quad n=2$

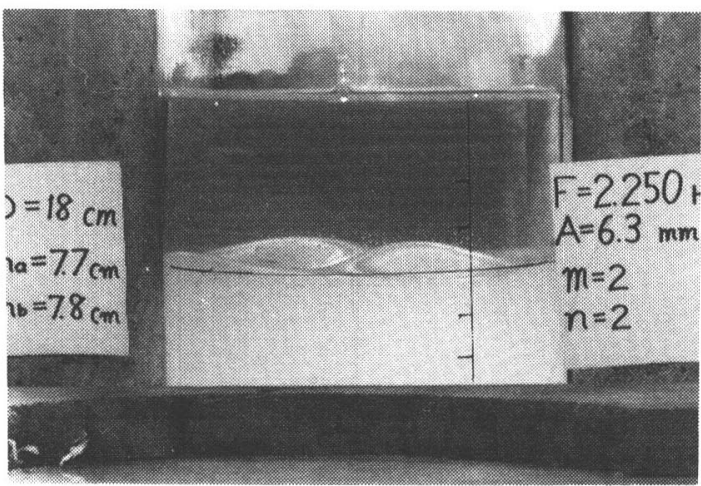

(b) $N \omega / 2 \pi=2.250 \mathrm{~Hz}, \quad m=2, n=2$
$7.7 \mathrm{~cm}, H_{b}=7.8 \mathrm{~cm}$ であり, 上層の表面はアクリル樹 脂製の蓋で密閉した。テレピン油の密度は温度によって 若干変化するが，ここでは測定の平均值 $G=0.864$ を用 いる.

実験の測定項目は

（1）振動台の振動数および振幅

（2）内部波のモード, 振動数および振幅

（3）内部波の減衰定数

である．測定項目（2）についてはテレピン油を用いて

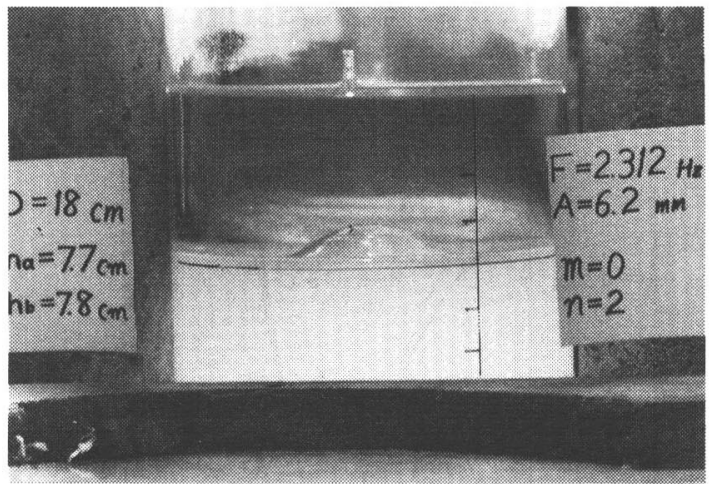

(c) $\quad N \omega / 2 \pi=2.312 \mathrm{~Hz}, \quad m=0, \quad n=2$

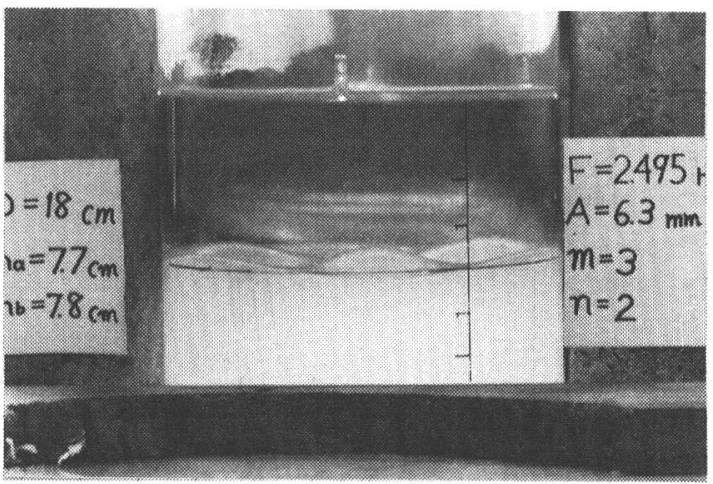

(d) $N \omega / 2 \pi=2.495 \mathrm{~Hz}, \quad m=3, \quad n=2$

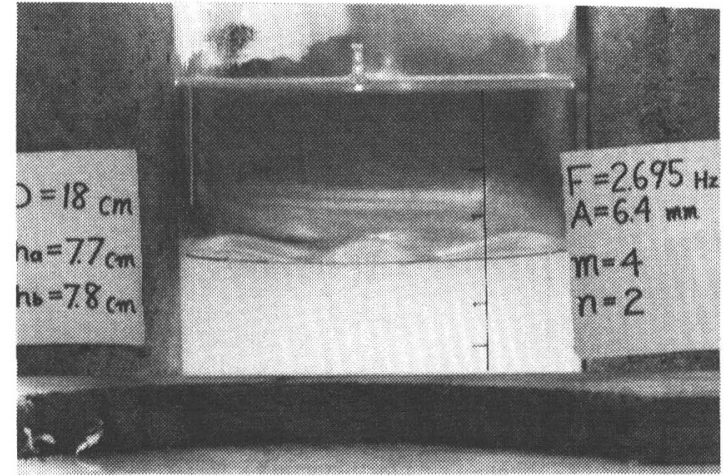

(e) $N \omega / 2 \pi=2.695 \mathrm{~Hz}, \quad m=4, \quad n=2$

Fig. 6 Modes of internal waves. 
いること，および上面が密閉されていることから波高計 を用いることが困難であるので, ビデオテープレコー ダーを用いて拡大した画面からモードを観察し，波高を 読み取った．また，内部波の振動数はストップウォッチ で測定した。

本実験において観察された内部波の様子を Fig. 6 に示 す。発生した内部波はすべて予想どおり，1/2-subharmonic $(N=2)$ 応答であった。 また，そのモードは $n$ $=2(m=0,1,2,3,4)$ および $n=3(m=1)$ のものが 観察された。発生した内部波はすべて重複波であり，円 周方向等への進行波成分はみられなかった. Fig. 6 の内 部波の形状について説明する．2. において述べたよう に $m$ は円周方向の波数であり，この值によって Bessel 関数の階数も決定される.内部波の形状がわかりやすい Fig. 6 中の (a) $m=1, n=2$, (c) $m=0, n=2$ の場合 を取り上げる. $m=0, m=1$ にそれぞれ対応する $J_{0}(x)$, $J_{1}(x)$ の $x$ に対する関数関係は Fig. 7 に示されているよ うになる. 同図中の矢印と $n$ の值は, 円周における境 界条件, 式 (8), を満足する位置およびその固有值の 順序を表わしている. $m=0$ (すなわち $J_{0}$ の場合）に対 しては, $n=1$ であれば内部波が中心で盛り上がってい る場合には円周では平均水面よりも下がっているはずで あるが, Fig. 6(c)では逆に円周付近で盛り上がっている. したがって, 2 番目の固有值 $n=2$ を取ることが判断さ れる. $m=1\left(J_{1}\right)$ の場合についても同様に Fig. 6(a)

と Fig. 7 を比較し， 2 番目の固有値 $n=2$ をとっている ことが知られる，同様にして，他のモ一ドに対応する波 形も決定される.

一層の単一液体で自由表面が存在し, 鈆直振動を受け

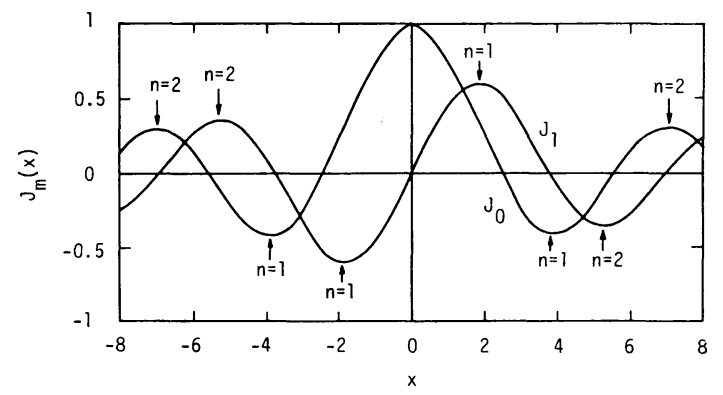

Fig. 7 Bessel functions which express lateral profiles of interfacial waves. Arrows indicate the positions where Eq. 8 are satisfied, for which $n$ is specified.

る場合には $n=1$ のモードが顥著に現われたが（文献 $3)$ ), 本実験では $n=1$ のモードは観察されなかった. この点については以上のような条件の相違に対して, そ れぞれのモードの時間的な発達率を Mathieu 方程式か ら調べる必要があると考えられる，本論文では発達率が 0 の場合について理論解析を行っているが, 発達率を論 ずる場合にはより複雑な取り扱いが必要とされるので, 現段階では実験で現われたモードについて説明を加える にとどめる.

各モ一ドの固有角周波数 $\Omega$ は式（15）から求まるが, この值を用いて $h=0$ の場合 (すなわち减衰のない場合) の安定・不安定領域を実軸上に描けば Fig. 8 のようにな り, 振動外力の振幅 $A$ が非常に小さくならない限り, ほとんどの不安定領域は互いに重なり合っている. 観察 されたそれぞれのモードの液面動摇はすべて予測された 領域内に収まっているが，互いに重なり合った部分では

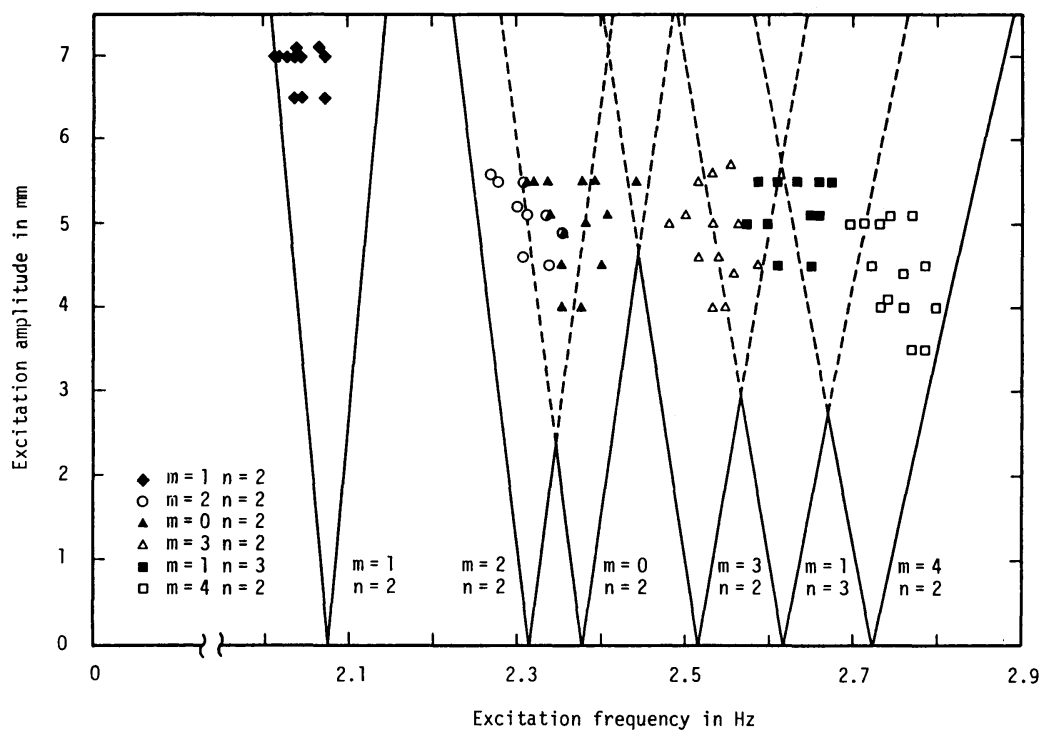

Fig. 8 Modes appeared in the present test. 


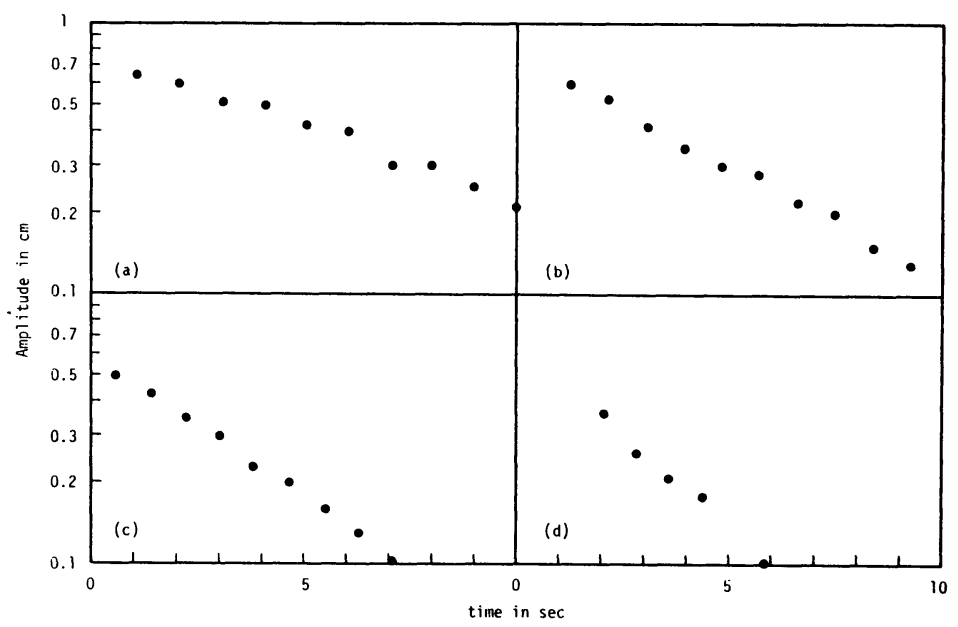

Table 1 Measured $h$ for each mode.

\begin{tabular}{lll}
\hline Mode & $h \Omega\left(s^{-1}\right)$ & $h$ \\
\hline$m=1$ & 0.121 & 0.019 \\
$n=2$ & & \\
\hline$m=2$ & 0.167 & 0.023 \\
$n=2$ & & \\
\hline $\begin{array}{l}m=3 \\
n=2\end{array}$ & 0.214 & 0.027 \\
\hline$m=4$ & 0.246 & 0.029 \\
$n=2$ & & \\
\hline
\end{tabular}

Fig. 9 Damping of amplitude with time for (a) $m=1, n=2$,

(b) $m=2, n=2$, (c) $m=3, n=2$ and (d) $m=4, n=2$.

主たる領域に近いモードの液面動摇が現われ，領域を分 割し合っていることが知られる. Fig. 8 にプロットされ ているのは液面動摇が現われた場合であり，現われな かった場合についてはプロットされていない. 本実験で は振幅が $3 \mathrm{~mm}$ 程度では内部境界面は全く安定であり， 動摇はみられなかった。これは前にも述べたように，粘 性による減衰項の効果であると考えられ，以下でこの点 について考察を行う.

减衰定数 $h$ は振動台を突然止め（このときを $t=0$ と する), 自由減衰振動をしている内部波の波高減衰を 0.01 秒刻みの夕イマーを入れたビデオテープレコー ダーから読み取り，この波高減衰を式（17）において
$A=0$ として得られる自由減衰振動の方程式から得られ る解と比較することにより得た. 減衰定数は各モード $(n$ $=2, m=1,2,3,4)$ についてそれぞれ $4 \sim 6$ 回測定した. $m=0, n=2$ のモードについては壁面での液面動摇が小 さく, $h$ の值を正確に测定することが困難であったので 省いている. 測定のばらつきは土 $15 \%$ 程度であった. たとえば, 後述される $m=3, n=2$ のモードでは Table 1 に示されているように $h$ の平均值は 0.027 であ るが, 6 回の測定のうち, 最小値は 0.021 , 最大値は 0.030 であった. タンク側壁における波の振幅の減衰の 状況を Fig. 9 に示す. 図中，縦軸が対数スケールになっ ていることに注意して, 振幅はほぼ指数関数的に減衰し
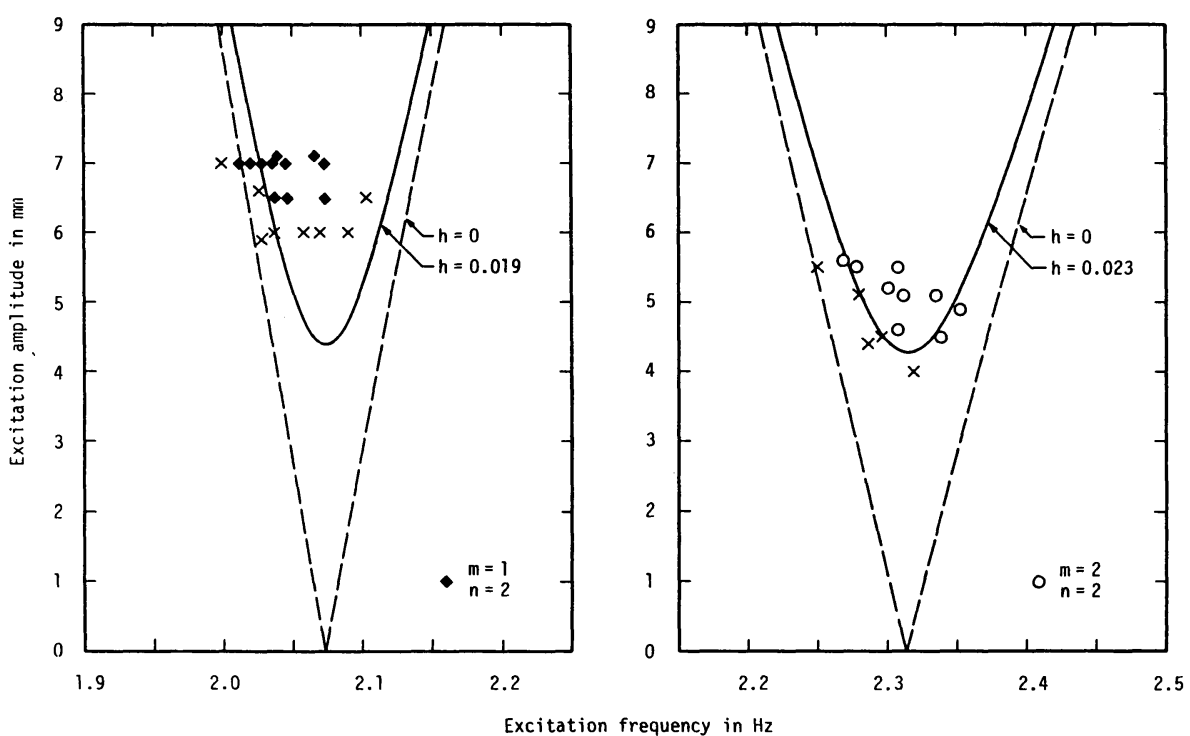

Fig. 10 Unstable regions of modes, $m=1, n=2$ and $m=2, n=2$. 

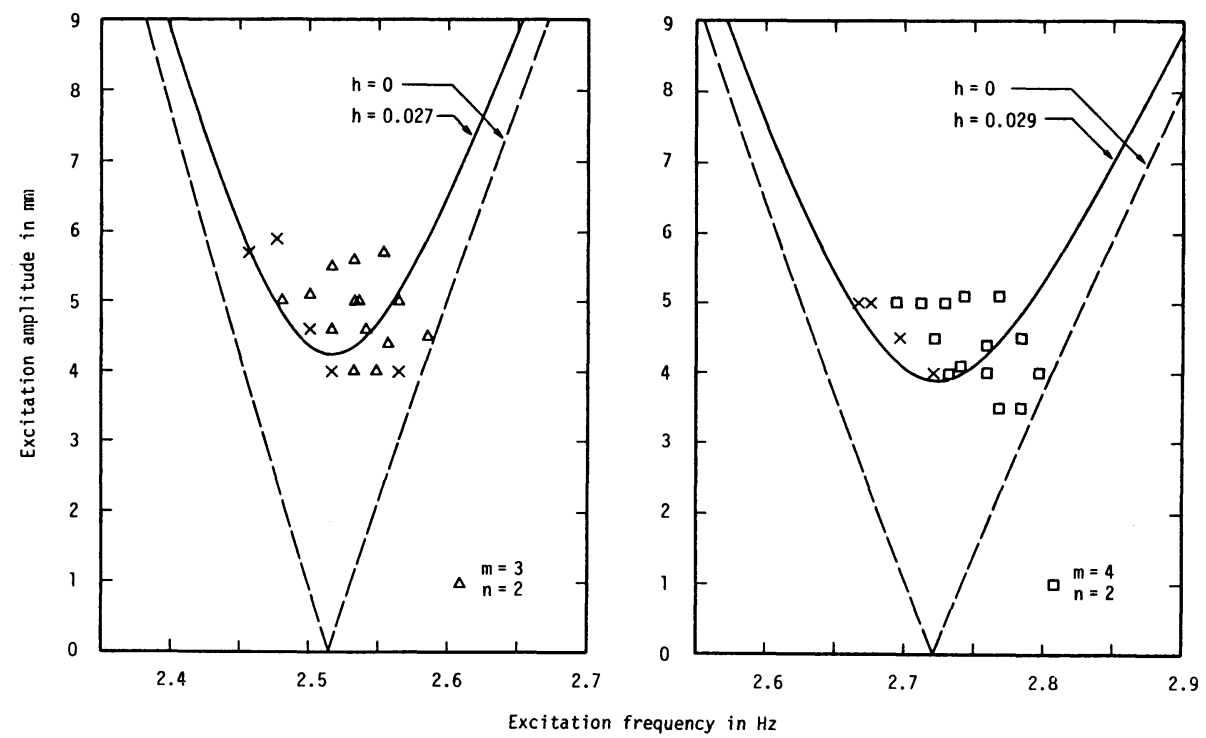

Fig. 11 Unstable regions of modes, $m=3, n=2$ and $m=4, n=2$.

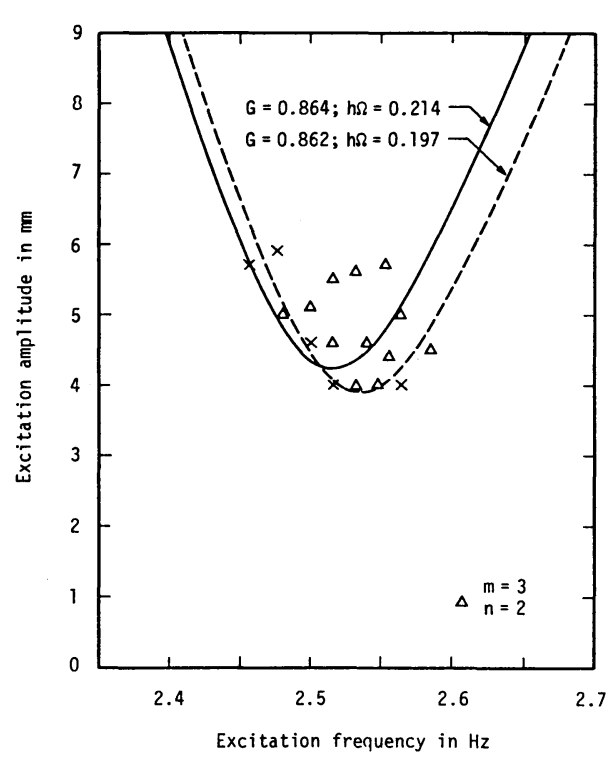

Fig. 12 Effects of $G$ and $h$ on unstable region for the case of mode, $m=3, n=2$.

ていることがわかる. 減衰率は Table 1 あるいは Fig. 9 に示されているように波数が大きいほど増加しており，

一般に知られている傾向と一致している.

以上のように, $h$ を測定した 4 個のモードについて, それぞれのモードごとに取り出して不安定領域をより詳 細に検討した結果を Fig. 10，11に示す. 図中，×印は 液面動摇が発生しなかった点である，网印よりも振幅が 小さい場合にはもちろん液面動摇は現われなかった。ま
た, 振幅が大きい点については振動台の性能上実験を行 うことができなかった（振動台の振幅は約 $8 \mathrm{~mm}$ 程度ま で可能である). モードによっては若干のずれがあるも のの, 測定された $h$ の值を用いて式 $(40)$ から計算さ れた安定・不安定境界 (実線) は実測による安定・不安 定境界を比較的よく表わしている.

次にこのずれの原因について若干の考察を行う. 前に も述べたようにテレピン油の比重は測定値の平均として $G=0.864$ を用いたが, 測定の誤差や温度によって変化 する.内部波は両液体の密度差によって決定されるので, テレピン油の比重の僅かな変化によってもかなりの影響 を受ける. 一方, $h$ の值もかなりの測定誤差を含んでい る. ここでは, $n=2, m=3$ のモードを例にとって $G$ と $h$ の効果について調べてみる. Fig. 12 は $G$ の值を 0.002 減少させ, また $h$ の值を $8 \%$ 減少させて $h=$ 0.025 として計算した安定・不安定境界 (破線) を示す ものである. $G$ も $h$ も測定の誤差の範囲内, あるいは 温度による変化の範囲内で変えているが, この程度の調 節で実測值と非常によく一致するようになることが知ら れる. 以上のように, 安定・不安定境界は $G$ や $h$ の変 化に対して比較的鋭敏に変わることがわかる.

\section{5. 結論}

本研究は鉛直振動を受ける円筒容器内に密閉された二 層液体界面に発生する内部波について, 理論的・実験的 研究を行ったものであって, その結果以下の諸点が明ら かとなった。

（1）内部波の安定・不安定を支配する方程式は 
Mathieu 方程式であって，このとき液体の粘性による 減衰項を考虑する必要がある.

（2）減衰項を考虑した Mathieu 方程式を $\varepsilon($ 鉛直 振動加速度／重力加速度に比例する量）についての高次 解を求めた. その結果, 解は少なくとも $\varepsilon^{2}$ のオーダー までとる必要があり, 減衰項は不安定領域を縮小させ, この不安定領域は実際上 1/2-subharmonic 領域におい てのみ現われることが知られた。

（3）二層夜体としてテレピン油と水を用いて実験を 行ったところ, 自由表面をもつ一層液体の場合にみられ た $n=1$ のモードは発生せず, $n=2$ 以上のモードが現 われた。現われたモードの発生領域は理論によってよく 説明することができた。 また，このとき，粘性減衰の効 果によって外力の振動振幅が小さい場合には内部波は発 生しなかったが, この安定・不安定境界についても理論 は実測值をよく説明した。

（4）この安定・不安定境界は内部夜体の密度差や減 衰定数の影響を比較的鋭敏に反映する.

謝辞：実験に際しては埼玉大学工学部建設基礎工 学科 中村広昭助手から援助を頂いた。また，堀川清司 埼玉大学客員教授から用語, 文献について助言を頂いた。 記して謝意を表します。

1) Benjamin, T.B. and Ursell, F. : The Stability of a Plane Free Surface of a Liquid in Vertical Periodic
Motion, Proc. Roy. Soc., A 225, pp. 505 515, 1954.

2) Dodge, F.T., Kana, D.D. and Abramson, H. N. : Liquid Surface Oscillations in Longitudinally Excited Rigid Cylindrical Containers, AIAA J., Vol.3, No.4, pp. $685 \sim 695,1965$.

3）池田駿介・秋山成興・中村広昭・白井伸一：円筒タンク 内の液体動摇に関する研究, 土木学会論文報告集, 290 号, pp. $53 \sim 65,1979$.

4) 和田 明: 原子力水理研究の現状と展望, 土木学会論文 集, No. 345/II-1, pp. 31 40, 1984.

5) Thorpe, S. A. : On Standing Internal Gravity Waves of Finite Amplitude, JFM, Vol. 32, Part 2, pp. 489 528, 1968.

6）石川忠晴 - 椎貝博美 : 円形水槽内 2 層流体における内部 波について, 土木学会論文報告集, 219 号, pp. 45 53, 1973.

7）沢本正樹 ·加藤一正：有限振幅内部重複波に関する研究, 土木学会論文報告集, 232 号, pp. 37〜47, 1974.

8) Bolotin, V. V. : The Dynamic Stability of Elastic Systems, Holden-Day Inc., San Francisco, 1964.

9) Hsu, C.S. : On the Parametric Excitation of a Dynamic System Having Multiple Degrees of Freedom, J. Appl. Mech., ASME, Vol. 30, pp. 363 372, 1963.

10) Lee, T. C. : A Study of Coupled Mathieu Equations by Use of Infinite Determinants, J. Appl. Mech., ASME, Vol. 43, pp. 349 352, 1976.

11) Takahashi, K. : An Approach to Investigate the Instability of the Multiple-Degree-of-Freedom Parametric Dynamic Systems, J. Sound and Vibration, Vol.78, pp. 519 $529,1981$.

(1986.6.11 • 受付) 